\title{
TTIP Negotiations: Interest Groups, Anti-TTIP Civil Society Campaigns and Public Opinion
}

\author{
Leif Johan Eliasson
}

East Stroudsburg University (jeliasson@esu.edu)*

\section{Patricia Garcia-Duran Huet}

\author{
University of Barcelona (patriciagarciaduran@ub.edu)
}

\begin{abstract}
The Transatlantic Trade and Investment Partnership (TTIP) was intended to create jobs and boost the economies on both sides of the Atlantic. However, constituency support was difficult to garnish, and negotiations were frozen in late 2016, leaving their conclusion in doubt. What led to this stage? Why has an agreement been elusive? Using an array of indicators this paper argues that a major reason was the extensive and professionally structured public mobilization campaign conducted by European civil society organizations (CSOs). This shifted public opinion across Europe, which in turn impacted policy. Our research contributes to the literatures on trade, lobbying, and transatlantic relations, with relevance beyond TTIP. The paper discusses how generalized and diffused interests and public opinion are impacting an area of public policy (trade) traditionally influenced predominantly by lobbying from narrowly focused interests.
\end{abstract}

Key words: Trade, TTIP, civil society organizations, lobbying, EU

*Corresponding author. jeliasson@esu.edu

Leif Johan Eliasson, Political Science, 200 Prospect Street, East Stroudsburg University, East Stroudsburg, PA 18301, USA +1570-422-3250 jeliasson@esu.edu

Dr. Leif Johan Eliasson is professor at East Stroudsburg University, Pennsylvania. He has authored two books, including America's Perceptions of Europe (2010, Palgrave MacMillan), and several book chapters, reports, and articles on trade, European integration, and transatlantic relations. These have appeared in publications such as European Public Policy, Journal of World Trade, Journal of Transatlantic Studies, and World Economy.

Patricia Garcia-Duran Huet, Faculty of Economics, University of Barcelona, Av. Diagonal, 690 E-08034 Barcelona +34-93-4021938 patriciagarciaduran@ub.edu

Dr. Patricia Garcia-Duran Huet is associate professor at the University of Barcelona and a member of the Observatory of European Foreign Policy, Institut Barcelona d'Estudis Internacionals (IBEI). She has published several book chapters and articles in refereed-journals in different languages. In the last few years, her work has focused on EU trade policy and the World Trade Organization.

Acknowledgment: The authors would like to acknowledge the helpful comments by participants at the EUSA 2015 Biennial Conference (Boston, USA) as well as two anonymous reviewers for this journal. The research for this article was supported by the Charles Koch Foundation and the Spanish Ministry of Economy and Competiveness (CSO2016-79205-P). 


\section{Introduction}

In November 2016 both European Trade Commissioner Malmström and German Chancellor Merkel declared Transatlantic Trade and Investment Partnership (TTIP) negotiations - ongoing since 2013 - frozen, while simultaneously expressing a desire to salvage what had been accomplished in a (potential) future revival. ${ }^{1}$ The negotiations were stumbling far prior to the election of Donald Trump as American president. Though his victory heralded major changes to US trade policy, including its withdrawal from the Transpacific Partnership Agreement, he expressed few opinions about TTIP during the campaign. So why could the US and the European Union (EU) not conclude a treaty?

Free trade traditionally enjoys support throughout Europe, especially in the northern half, and EU trade negotiations (perceived as technical and remote) have rarely evoked public interest. $^{2}$ At the same time, many trade agreements often face resistance from select groups and specific portions of the general population who believe they may experience immediate and focused costs, notwithstanding potential - but diffused - long-term benefits to the overall economy. ${ }^{3}$ In regards to TTIP, deep transatlantic economic interpenetration and interdependence means most sectors on both sides of the Atlantic would be affected, with macro-economic gains projected for both sides, even if certain sectors would benefit more. ${ }^{4}$ The negotiations were also presented by the EU and the US leadership as a joint transatlantic effort aimed at addressing stagnant growth and unemployment, while also setting global standards at a time of rising competition from emerging powers. ${ }^{5}$ 
However, the focus of the debate quickly changed away from the agreement's economic and rule-setting potential as an organized opposition emerged, concentrated in Europe. ${ }^{6}$ The projected benefits to the European and American economies were questioned, and the potential costs associated with an agreement were increasingly deemed extraordinarily high by European consumer, welfare, and environmental organizations, as well as more radical and populist antiglobalization and anti-capitalist groups, and labor unions (all here collectively referred to as civil society organizations, CSOs). ${ }^{7}$ The advantages enjoyed by business groups favoring free trade (e.g. TABC, BusinessEurope), such as access to the Commission and national governments, were overshadowed by CSOs and unions. These groups mounted an extraordinary and ubiquitous campaign, moving public opinion against TTIP. ${ }^{8}$ Opponents challenged the Commission, US Government, and other proponents' claims of prospective economic gains, job creation, and higher safety and regulatory standards. Opposition mobilization occurred through social media and traditional street protests, while also garnering increased attention from mainstream media; the latter being important in order to capture the attention of policy makers and sustain campaigns. ${ }^{9}$ The Commission, national governments, and most business organizations were unprepared for the unprecedented and coordinated onslaught through social media, physical protests in rallies and marches, and targeted lobbying of legislators. ${ }^{10}$

TTIP had been predicted difficult to conclude, and the protectionist rhetoric dominating the 2016 US presidential election campaign certainly did not help, but European developments are largely responsible for the freezing of negotiations. ${ }^{11}$ Opponents' actions have led EU negotiators to alter their approach in ways seen implausible only a few years ago; in other words, affecting agenda setting, the procedure (how), and policy (what). The promise of 'continued dialogue' with stakeholders and civil society groups was, as one Commission official admitted, 
an acknowledgement that CSOs' 'push' and 'opposition' and altered public sentiments have affected how they reviewed Investor-State Dispute Settlement (ISDS) and how they decided to go forward with the messaging. ${ }^{12}$ A representative of a transatlantic business organization acknowledged in 2015,

[t]hey [industry] realize now that civil society groups now have an advantage in the marketing of TTIP and TTIP issues, and that businesses have difficulties in getting across their concerns and issues and difficulty conveying the truth and countering misperceptions distributed by public interest groups. There are intense discussions now on how to counter misperceptions and promote TTIP. ${ }^{13}$

This paper identifies and explains how pan-European and national organizations organized opposition to TTIP; why certain key issues were strategically chosen, and how certain words and phrases were utilized to raise public salience and mobilize opposition. ${ }^{14}$ The increased salience of issues in TTIP in the eyes of ordinary Europeans then contributed to changing public opinion, as well as increasingly effective fund raising for participating CSOs. This in turn allowed opposition groups to significantly increase their staff with both sympathetic issue specialists and campaign strategists. European opposition groups' dominance of the public debate correlate with declining European public support for TTIP, rendering an agreement highly doubtful. These insights contribute to the literatures on trade, lobbying, and transatlantic relations. More specifically, this paper discusses how a campaign targeting key issues while appealing to generalized and diffused interests and public opinion impact a specific area of public policy (trade). ${ }^{15}$ The next section shows how the literature on framing and public perception can explain the anti-TTIP strategy and campaign. We thereafter look at the impact on public opinion, while the last section concludes. 


\section{Anti-TTIP group mobilization and issue choices}

Notwithstanding attempts to present the anti-TTIP opposition as 'grass-roots', the campaign against TTIP has been a highly professionalized, top-down, trans-European campaign. ${ }^{16}$ The initial suspicion toward TTIP came largely from mainstream CSOs (e.g. BEUC, Public Citizen, Friends of the Earth Europe), whose concerns focused on the perceived threat to EU safety and food standards (which they argued were higher than America's) emanating from the much touted regulatory focus in TTIP. The argument was that both mutual recognition and recognition of equivalency of each other's standards create a 'race to the bottom' on standards in order to attract investments. ${ }^{17}$ These groups produced campaign material independently, but also worked with other groups under an umbrella organization called StopTTIP, which boasted of over 200 participating organizations. But why were certain strategies and issues chosen? How have they succeeded?

Politics is about perceptions, and for agreements requiring European Parliamentary and domestic legislative ratification constituency perceptions matter. Dür $(2015: 7,25)$ finds that interest groups can shape public opinion in line with their preferences via frames, meaning a particular emphasis on and interpretation of an event (e.g. 'this arbitration case shows how corporations circumvent democracy'), while cues, information used to infer other information the recipient does not possess (e.g. the Greens oppose ISDS, therefore I should oppose ISDS), matter less in shaping opinion. ${ }^{18}$ Thus, while CSOs still use 'inside' tactics (e.g. letters to officials and personal meetings), 'outside' tactics (e.g. demonstrations and petitions), ${ }^{19}$ social media, postings and creative propaganda websites, they may be more effective in disseminating interpretations when framing issues in their favor rather than sending cues. CSOs also generally 
enjoy higher public trust than the EU, national governments, or corporations, placing them in a better position to shape public opinion via frames. ${ }^{20}$

Receptivity to frames is facilitated by how they are designed. Humans are more receptive to fear than positive messaging; later-in-time information remains more relevant than earlier information, and negatives (e.g. economic pain) are perceived more strongly than benefits. ${ }^{21}$ Hence, opponents' messaging is expected to have a higher impact the more fear it is able to convey to the population and the more continuous the messaging. Another key characteristic of good framing is its link with existing beliefs. Perceptions do not necessarily rest on logical and sound premises; in fact, they may contain only a kernel of truth in order to gain traction. ${ }^{22}$ Human preferences for consistency and simplicity means there is a tendency to accept information conforming to one's expectations, and to interpret evidence, whatever its nature and strength, as validating existing beliefs. ${ }^{23}$ To prevent cognitive dissonance people also erect filters that stop information perceived to be inconsistent with or contradictory to one's expectations (which are based on preconceived notions and worldviews). ${ }^{24}$ The result is acceptance of both information and propaganda, but with difficulty distinguishing between the two, and increased likelihood of accepting and disseminating distortions of reality - such as stories with omitted or misrepresented facts - to other audiences, creating myths. ${ }^{25}$

Political actors, including interest groups and unions, can achieve the desired reaction in the public by choosing specific issues to simplify and emphasize. Such campaigns may include appealing to product or process associations to elicit a response. Thus, if chemicals (A) are associated with poison (B), associating a different product or issue (C) with A can elicit a negative response to C. Once salience is raised in the targeted population and supporters rallied, 
other groups also tend to mobilize for the cause (while simultaneously seeking to gain attention, membership, and funds, all of which increase mobilization resources) creating a snowball or avalanche effect. ${ }^{26}$ By 'making a fuss' about the chosen issues and processes groups are also more likely to receive news coverage of their message (which increases the likelihood of the desired effect). ${ }^{27}$ In sum, fear-filled information, especially when building on general and negative perceptions, gets public attention, so choosing the 'correct' issue(s) is essential.

Opposition CSOs needed specific words and phrases to educate and rally citizens. Ordinary citizens cannot be expected to engage on obscure issues and opaque trade negotiations, so, as one CSO representative confided, we "needed something to raise fears and capture attention.' No organization provided more ammunition to anti-TTIP groups than Campact. Founded in Aachen, Germany, from which Attac (an experienced organization opposing globalization, capitalism, and TTIP) also stems. Campact first emerged as active on policy when campaigning for green labelling on products, at which time it gathered 800,000 email addresses. This list rose to nearly two million by 2016 . The organization promotes and engages on ideas provided by other groups and individuals, but most importantly serves as a source of pivotal data and support. Campact provides material, raises money through town hall events and online donations, disperses money to groups and campaigns, but does not serve as the primary organizer of anti-TTIP protests. ${ }^{28}$ Its tactics work effectively as force multipliers. Campact conducts market tests on policies requested by the client by using phrases and words on the topic or issue. It takes a name or process, ties it to a policy, and sends a query to targeted e-mails drawn from its list-serve. Building on the responses the message is modified, and the product, action, or process is associated with something negative (e.g. chicken and chemicals, or ISDS and circumventing 
democracy) before being retested. The client is then provided the results, or campaign 'fuel' (e.g. which words, phrases, or associations evoked certain desired reactions). The phrases and words shown to resonate with citizens are used not only in campaigns, but also when seeking funding from donors for specific activities, another Campact specialty. ${ }^{29}$ Their 'infrastructure for political education' includes donations (over $€ 140,000$ ) to groups across several EU Member States; much of the money is raised through small online and town hall donations. ${ }^{30}$

Specific issues such as food and investor rights were chosen not primarily because they represent issues on which groups would have the best chances of influencing policy proposals, but rather because they help raise the salience of TTIP generally, which in turn allows lobbying, protests, and campaigns also on technical details and other specifics. ${ }^{31}$ The American process of chlorinated microbial wash of poultry was a natural choice of focus as it connected an appealing food (chicken) with chemicals (chlorine) ${ }^{32}$ For most Europeans the significance of food extends far beyond its nutritional value; it is an essential part of life, where caution prevails and discussions of recognizing others' standards raise concerns. ${ }^{33}$ Sixty percent of European check the origin of their food, and for nearly half the origin influences their purchase. ${ }^{34}$ This is higher than for any other category of products, indicating awareness of and concern with food, and likely higher receptivity to public campaigns regarding issues related to food. Furthermore, the precautionary principle guides EU food policy, and groups have successfully appealed to Europeans' relationship with food.

'It is not without reason that chlorinated chicken has emerged as a symbol of the detriments European consumers might face if a TTIP deal is signed... [t]he European approach to meat safety is more efficient in protecting public health,' and that the 
American approach is "[t]he "easy fix" to make up for poor farming and slaughter hygiene. ${ }^{, 35}$

The prevailing norm of objection to GMOs is also deeply entrenched as only $21 \%$ believe they are safe. ${ }^{36}$ While Europeans widely support science and technology as the bases for policy and progress, the exception is food, where less than half believe science can improve food quality. ${ }^{37}$ This was manifest when the EU's chief science adviser publicly and repeatedly urged more evidence-based decisions, only to be forced out following political outcry over her views. ${ }^{38}$

CSOs present American standards as 'weak' and 'less safe,' as reflected in position papers, social media posts, online videos, protests, and public statements, and key European publics have increasingly agreed. ${ }^{39}$ Foodwatch, an anti-corporation group founded in 2001 and involved in raising awareness on issues such as mad cow disease, chemicals, and GMOs, entered the TTIP fray in 2014. Thilo Bode - the charismatic leader whose 2015 book Die Freihandelslüge was a best-seller in Germany - effectively used selective trigger words and provocative framing in public speeches and debates in order to win of over public support against TTIP, the provisions of which he asserts 'serve big business instead of ordinary people, and they undermine our democratic standards. ${ }^{40}$ Raising public salience on food was thus primarily an issue of presenting the specifics of sanitary and phytosanitary standards (SPS) as a threat to Europeans' health in a simplified and understandable fashion.

ISDS was quickly deemed a useful target which could be drastically simplified to the general public in order to garner attention and raise awareness of TTIP. The dispute settlement system is intended to ensure that foreign investors have access to de-politicized legal redress for compensation (not legislative changes) when a host country's government violates the terms of the investment treaty. ${ }^{41}$ Though Europeans have longstanding experience with ISDS through 
Bilateral Investment Agreements (BITs) - which began in Europe after WWII as investors wanted assurances when investing in former colonies (EU states have signed 1,400 BITs, many with ISDS, compared with fewer than 50 BITs signed by the US) - it was unknown to the general public (as well as many CSOs, labor unions, and policy makers) prior to $2013 .{ }^{42}$ Yet 'Allowing corporations to sue governments in secret courts over policies they don't like' and 'threatening public services' tested well, and became mantras continuously repeated in protests and panel discussions, in YouTube videos, tweets, position papers, reports, and press releases.

The anti-TTIP campaign was a great boom for 'campaign companies' such as 38 Degrees, Campact, and Attac, for whose 'business models, TTIP provides an ideal breeding ground to increase brand awareness and funding, respectively. ${ }^{43}$ Campact doubled the number of employees, to a professional staff of three dozen people and a budget of 6 million euros, or about $\$ 6.8$ million, annually. ${ }^{44}$ Similarly, other opposition groups also enjoyed rising donations (in addition to the grants many receive from the EU), and hired trade specialists from government and academia, adding additional in-house expertise while boosting the credibility of their cause. ${ }^{45}$ Legal experts toiling in obscurity on ISDS (some of whom had been told when submitting academic papers that 'this is not important') were suddenly coveted as the concept of investors suing governments using secret arbitration panels tested well. The extensive penetration of trade specialists (including academics) in opposition groups provided an aura of professionalism and seriousness to the campaign. These groups were many aspects as wellorganized as the business organizations and lobbyists they criticize.

\section{Anti-TTIP Propaganda and Public Opinion}


The combination of professional testing, mass mobilization, tech-savvy employees, and proliferation of mobile, easy-to-use social media meant that the years 2014-2016 saw an effective, highly asymmetrical, anti-TTIP propaganda apparatus. ${ }^{46}$ TV remained the most popular source of information across the EU in 2016, while newspapers retained a significant share among those 55 and older, thus making traditional media attention crucial for opposition groups seeking to raise salience and attract supporters. However, six out of ten EU citizens, and half of young people $(<35)$, as well as those with a college degree, get news from the web, including social media sources (of which Facebook, Youtube and twitter are the most popular). ${ }^{47}$ This helps to (partly) explain both the anti-TTIP campaign's focus on social media ('that's where people are'), and the campaign's success, as cleverly constructed information (read: propaganda) and advertisements frame people's perceptions of TTIP. The European Commission instructed its staff and member states on the need for 'strong political communication' in order to 'define the terms of debate' on TTIP, ${ }^{48}$ not unlike the way the US Administration and USTR attempted to set the terms of debate on TPP, but with little success.

In the fall of 2013 CSOs and unions staged protests and published policy papers opposing ISDS. The opposition was so intense that in January 2014 a negotiating pause on the issue was announced, during which the public would be consulted. In July 2014, led by StopTTIP!, the Commission was presented with a European Citizens Initiative with more than one-million European signatures petitioning it to alter negotiations (remove ISDS) and hold hearings in Parliament. ${ }^{49}$ While dismissed (petitioners were informed that the petition process is inapplicable to preparatory decisions), it succeeded in generating further outcry from citizen groups, while generating media coverage across Europe. In an online world, participation in petitions serve as a way of expressing opinion, and when covered by the media this in turn helps convey the anti- 
TTIP message to larger audiences. Throughout the year think tanks, academics, and law centers also issued policy papers, commentaries on past and ongoing arbitrations, and held panel debates. ${ }^{50}$ By mid-2015 the Citizens Initiative has gathered two million signatures, while the US Congress in turn debated trade promotion authority legislation requiring ISDS in trade agreements, providing additional fuel for European opponents. ${ }^{51}$

Following the January 2015 press release of the results of the public consultation, the Commission promised months of stakeholder dialogue and possible refinements to ISDS. This was met with indignation from CSOs. ${ }^{52}$ Opposition CSOs had collectively amassed 150,000 signatures against ISDS, predominantly by getting citizens to contribute pre-formatted submissions against ISDS (96\% came from Austria, Germany, the UK, France, Belgium, Netherlands and Spain). Notwithstanding the tactics, the fact that $97 \%$ of submissions were in opposition to ISDS in TTIP was widely publicized and used by CSOs, putting pressure on the Commission to act on the issue. In September 2015 the Commission responded -with a revised ISDS, in the form of extensive curtailments on how, when, and where investors could challenge government decisions as well as a permanent Investor Court System (ICS). This succeeded in generating both derision and protest from CSOs, as well as opposition from nearly every other interested party. ${ }^{53}$ US officials and transatlantic business groups deemed the proposal too restrictive, while also noting the near-certain Congressional rejection of a new international court. $^{54}$

Opposition CSOs made effective use of selective data, simplifications, exaggerations, and distortions, especially in social media disseminations, while simultaneously attracting attention from the traditional media. While thousands of events were held across Europe in 2014-2016 by groups and organizations both supporting and opposing TTIP, the opposition was especially 
active on the continent. In Germany 'Well over 75\% of TTIP events have been organized by opponents, and by one estimate 42 of the fifty most requested and cited experts (read: people to comment on TTIP) in 2015 were against TTIP. ${ }^{55}$ Horrific images and ideologically grounded, creative and manipulative slogans such as 'TTIP kills,', 'Stop (t) TTIP,' 'TTIP is an attack on our democracy,' and 'Tango against TTIP' dominated the discourse, as the negative connotations intended to activate resistance. ${ }^{56}$ CSOs mustered an estimated 250,000 protesters into the streets of Berlin on October 10, 2015. Meanwhile, Germany's economy minister published a full-page letter in several major newspapers on the day of the protest to urge against scaremongering. As one scholar noted,

Unfortunately, anti-TTIP groups keep on spreading speculations and risks that are completely irrelevant and frequently taken out of the blue...Due to Campact's efforts, we have arrived at a stage where German citizens' interest in TTIP is 25 times higher than in the US and roughly 15 times higher than in France. The sad thing is, however, that most citizens are simply misinformed, e.g. by paid-for Google advertisements set up by antiTTIP groups. ${ }^{57}$

Publicity surrounding the fall 2015 release of the EU's ICS to replace ISDS also generated increased online searches on the issue. Internet search frequency is one reflection of an issue's salience, and while there were no discernable volumes prior to June 2013, the following year saw Germany register the most TTIP web searches, followed by Austria and Belgium, the three countries with the largest anti-TTIP movements and most CSO activity. ${ }^{58}$ Bauer (2015) found that

85 per cent of all TTIP-related positions in German online media are originally authored and spread by anti-TTIP groups. Similarly, for the period July-December 2014, anti-TTIP groups' announcements in Germany amounted to 83 per cent of total online media reporting on average, going up to 93 per cent in peak times. ... around the TTIP negotiations rounds, and it is obvious that there are coordinated multi-online-media campaigns with high success rates. 
Online TTIP searches in each of the three EU Member States with the largest anti-TTIP movements (Germany, Belgium, Austria), and in three of the most populous Member States (France, United Kingdom and Italy) between January 2013 and February 2017 showed similar

trends. ${ }^{59}$ Searches peaked around the negotiating rounds and CSO-led street protests in early and late 2014, January and October 2015, April 2016, and September-October 2016, when the EUCanada Comprehensive Economic and Trade Agreement (CETA) figured prominently in the European press, and was frequently linked to TTIP. Trade was also hotly debated in the US election (worrying some Europeans), and the last TTIP negotiating round of 2016 took place in New York.

\section{REFERNCE TO ONLINE SUPPLEMENTAL GRAPH 1 SOMEWHERE HERE}

YouTube searches on TTIP also peaked around the same dates as web searches, and in regards to the content found on YouTube the results were similar to those of a google search. ${ }^{60}$ When googling TTIP in Germany one was first exposed to paid advertisements from opposition groups (e.g. Foodwatch), followed by a news headline, and thereafter several more anti-TTIP links. ${ }^{61}$ 'TTIP kills,' 'Stop TTIP' and similar slogans thus dominate the information Germans get when using the internet to find information on TTIP, creating and reinforcing negative perceptions. Anecdotally, our own December 2014 and May 2016 TTIP searches on Youtube yielded 16 and 19 of the 20 first results on Youtube being explicitly anti-TTIP. Furthermore, as Ciofu and Stefanatu (2016) show, 'Tweets that include hashtag words generally favorable to the agreement only make up roughly $1 \%$ of total tweets, whereas tweets advocating a clear no (through hashtags like \#stopttip, \#nottip, \#noalttip and others) represent 99\% of total TTIP related activity' on Twitter. Fact checking on the web, including social media sites, occurs 
through exchanges (debate), where balanced views are not required, reinforcing negative messages.

\section{REFERNCE TO ONLINE SUPPLEMENTAL GRAPH 2 SOMEWHERE HERE}

The Google Trends for ISDS show, in general, a similar pattern to TTIP. ${ }^{62}$ Nevertheless, differences can be observed at country level, where ISDS was consistently of high interest in Germany while it tended to increase around negotiations, protests and intense campaign activism in other countries.

Opposition to ISDS also worked its way into governments, with France and Germany expressing desires for a renegotiation of the ISDS clause in CETA before the Commission's revised ICS, and support for similar text in TTIP. ${ }^{63}$ Opposition was also visible later, at the October 2016 near-fatal objections to the CETA text by the regional Belgian parliament in Wallonia. ${ }^{64}$ There was significant regional public opposition stemming from the antiTTIP/CETA campaign's assertions of how allowing ICS could hurt public policy, and the opposition found great receptivity in Wallonia's socialist prime minister. Following immense pressure from other EU leaders he agreed to sign only after the EU issued a 'binding declaration on ICS' and approved a referral to the Court of Justice of the European Union to rule on ICS compatibility with EU treaties. ${ }^{65}$

Europe's long, favorable and expansive history of trade agreements could be expected to mitigate at least some of the negative messaging of TTIP; even in the depth of the financial crisis (2010) $65 \%$ of Europeans said the EU benefitted from international trade, and general support for free trade stood at $69 \%$ in $2016 .{ }^{66}$ Yet, support for TTIP across the EU has fallen, and in some larger EU countries fairly dramatically, correlating with a continuous campaign asserting 
the possibility or potentiality of having to accept GMOs, chlorinated chicken, companies suing governments, and privatization of public services.

The opposition campaign's focus on SPS (food safety issues) intensified in 2014. In a June 2014 open letter, which was either published or referenced by several news prominent European outlets, three leading civil society groups argued,

...fair, sustainable and safe food could permanently be damaged by the transatlantic trade deal on the table....[T] he WTO SPS agreement has been disproportionately used by the US (on behalf of agribusiness) to challenge EU standards on a wide range of food safety measure. $[\mathrm{W}] \mathrm{e}$ cannot have confidence that the draft measures designed to expedite agricultural and food trade between Europe and America will uphold to the highest standards the food safety safeguards that protect consumers and animals. ${ }^{67}$

The anti-TTIP campaign tapped into this skepticism, frequently presenting American food as chemically enhanced and driven by large-scale industrial output, in a society that has no food culture. ${ }^{68}$ Appealing to the public about the possibility, however remote, of having to accept GMOs, chlorinated chicken and companies suing governments worked exceptionally well. The recipient notices the action or threat (chlorine chicken, sue governments) rather than the modal verbs signaling a remote possibility. Only $30 \%$ of Europeans expressed concerns about residues such as antibiotics or hormones in meat in 2010 - before any talk of a trade agreement - but in 2014 there was great resistance to accepting American standards or altering what is perceived as higher Europeans standards. ${ }^{69}$

In the UK opposition groups deliberately played up the potentiality of privatizing the National Health Service (NHS) as a consequence of regulatory convergence and forced competition. ${ }^{70}$ Despite continuous government assurances to the contrary, the percentage of British respondents who believed the government could protect the NHS dropped twenty-four percentage points the first year of negotiations; 39\% thought TTIP would harm small business, 
and more than half did not trust the government to negotiate a deal in Britain's best interest. ${ }^{71}$ One year later only $19 \%$ thought TTIP 'was a good thing,' even though $44 \%$ believed it would create British jobs; however, only one in six admitted following TTIP 'closely. ${ }^{72}$

While the aspects of TTIP debated in most business and EU circles differ from those promoted on social networks, the goal for all participants is to influence public opinion to one's advantage and, in this way, to exert pressure on policymakers. Opposition groups have been very good at this. With little public knowledge of ISDS, and an early focus on the issue, CSOs and unions could shape opinion by stressing the negative cases (where private companies had sued governments) and future danger with ISDS, in addition to the scaremongering on food issues. Online searches for TTIP or ISDS show a crushing majority conveying - often well-scripted negative messages; thus it was unsurprising that people began believing this story. The polls suggest the anti-TTIP campaign strategy worked. In an April 2014 Pew survey 55\% of Germans thought TTIP was 'a good thing', and $88 \%$ said the same thing about trade in general; five months later only 39\% supported TTIP, falling to one-in-five by May 2016. Austria exhibited a similar decline. In no country did support increase between November 2014 and May 2016. There is also no correlation between general support for trade and specific support for TTIP, another indication that anti-TTIP propaganda and protests have impacted public opinion, while supporters struggled to convey their message. ${ }^{73}$

\section{Graph on Public Opinion HERE}

Even the European Parliament, where pro-trade sentiments normally override ideological and Europhile-euroskeptic divides, responded to the campaign, and the bombardment of anti- 
TTIP emails and constituency protests. In October 2012 the European Parliament voted 526-92 for a resolution calling for the commencement of negotiations on a TTIP. Twenty-six months later the lead report by the Committee on International Trade was highly critical, and the June 2015 resolution of continued support had to be postponed a month, with further revisions, when the Socialist group threatened to oppose the resolution because of internal divisions over ISDS. ${ }^{74}$ Furthermore, the argument that because negotiations occur behind closed doors the participating parties must be hiding something conveniently omits that not only is this standard negotiating practice and necessary for frank discussions (which can lead to acceptable compromises), but every previous treaty was also negotiated in the same fashion, by the Commission based on a mandate from elected national governments

\section{Conclusion}

This paper makes two contributions to the literatures on trade, lobbying, and transatlantic relations. Together they indicate that transatlantic relations (deeper integration between the US and the EU) were being challenged even before Donald Trump became president, and that lobbying in trade may no longer be limited to narrowly focused interests, such that even a finalized TTIP agreement would face serious problems with ratification in many Member States. $^{75}$

The first contribution has to do with how key pan-European and national organizations are able to mobilize generalized and diffused interests and public opinion. Despite its novelty and relatively limited resources (compared to business organizations) the anti-TTIP campaign in Europe has been able to raise public salience and mobilize public opinion by choosing the 'correct' issues, words, and phrases. Democracy's freedom of speech entails competition over 
ideas, values, and policy. It allows the dissemination of ideas irrespective of whether they are true, or even partially accurate, and social media enable disseminators to promulgate truths as well as unsubstantiated and/or unverified claims, while leaving the determination of what is true in the hands (minds) of the recipient. Alarmist, fear-filled messaging tends to be more impactful than facts, and when faced with conflicting opinions, those holding positive views tend to remain silent, allowing the more critical crowd to dominate the discussion.

The second contribution has to do with how generalized and diffused interests and public opinion are impacting an area of public policy (trade) traditionally influenced largely by lobbying from narrowly focused interests. The timing of searches on Google and YouTube indicate that the public debate has been impacted by European opposition groups' actions and that there is a correlation between these results and declining European public support for TTIP.

${ }^{1}$ Brussels Briefing on Trade, November 12, at

http://www.borderlex.eu/eutradeinsights/malmstrom-ttip-to-remain-in-a-freezer-for-quite-some-

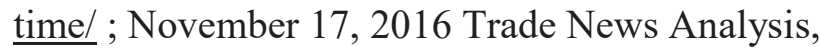
https://twitter.com/TradeNewsCentre/status/799312181670055938

${ }^{2}$ Opposition campaigns and protests have been conspicuously absent from the EU-Japan negotiations on a free trade agreement (FTA), which commenced six months prior to TTIP, and other negotiations, such as between the EU and Vietnam negotiations, which concluded in 2016. ${ }^{3}$ See e.g. James Q. Wilson, The Politics of Regulation New York, NY: Basic Books (1980). 
${ }^{4}$ E.g. Gabriel Felbermayr et al. 'Transatlantic Trade and Investment Partnership (TTIP): Who benefits from a free trade deal?' Global Economic Dynamics Paper, Gütersloh: Bertelsmann Stiftung (2013); Jean François, et al. 'Reducing Transatlantic Barriers to Trade and Investment An Economic Assessment', Final Report for the European Commission, Contract TRADE10/A2/A16, Center for Economic Policy Research, London (2013). It would be expected that participants in the highly protected and subsidized agricultural sector oppose liberalization; it is in fact the only sector without transatlantic coordination in favor of TTIP. cf Alasdair Young, 'Not your parents' trade politics: the Transatlantic Trade and Investment Partnership negotiations', Review of International Political Economy, Online March 28, DOI: 10.1080/09692290.2016.1150316. European farmers (more heavily subsidized and representing more family farms than in the US) generally oppose TTIP, and its most sensitive products were never even seriously considered for complete tariff removal. Interviews Brussels, May 2016 and Washington DC, January 2017.

${ }^{5}$ Final Report High Level Working Groupon Jobs and Growth (February 11, 2013), http://trade.ec.europa.eu/doclib/docs/2013/february/tradoc_150519.pdf

${ }^{6}$ This paper focuses on the European side of CSO activities. Though there has been plenty of transatlantic cooperation and coordination among TTIP opposition groups - with American CSOs advising their European peers on issues such as Investor-State Dispute Settlements (ISDS), co-authoring letters to legislators, and coordinating protests -American groups focused primarily on TPP in 2015 and 2016. Some American CSOs also supported European efforts to 
stop TTIP, as revealed in author interviews with representatives in Washington DC, January 2017.

${ }^{7}$ As applied here CSOs include what Berry 1999 in Andreas Dür and Gemma Mateo Insiders versus Outsiders: Interest Group Politics in Multilevel Europe Oxford: Oxford University Press (2016) call citizen groups, or public interest groups, and are focused on animal welfare, consumer interests, public health and environmental causes, and international development. Labor unions spoke favorably of TTIP even before its formal launch, recognizing the favorable labor standards in the EU, and the largest American labor union, AFL/CIO, privately expressed hopes that TTIP could help improve labor standards in the US (Interview, Washington DC, October 2012).

${ }^{8}$ Space limitations prevent a deep discussion but it is necessary to highlight that opponents to TTIP can largely be divided into two camps. The reformers would accept an agreement with the US if, in their view, there were substantial revisions to proposals, including enhanced guarantees on protecting human and plant health, higher safety standards, and curtailment of what they deem corporate power. Reformers include CSOs such as the European Consumer Organization (BEUC). Labor unions, which have always been active on trade, are also reformists, though with more unacceptable 'red lines'; they are seen as closer to the rejectionist camp (with groups such as Attac, Corporate Observatory, and War on Want, all part of the StopTTIP! Alliance, all with previous experience opposing globalization, capitalism and trade). This group opposes an agreement under any circumstance, premised on arguments that modern trade policies are the manifestation of globalization and neo-liberalism which exploits ordinary people. Though the 
two camps are joined in a cause and cooperate on protests, they differ slightly in their approaches. Reformists tend to engage in insider lobbying, public debates with trade supporters, and peaceful street protests; they also use a less confrontational social media campaign than rejectionists. E.g. Giovanni Gortanutti, 'The influence of trade unions and social movements on EU trade policy.' Paper presented at EU Trade Policy at the Crossroads: between Economic Liberalism and Democratic Challenges, Österreichische Forschungsstiftung für internationale Entwicklungspolitik, February 4-6, 2016.

${ }^{9}$ E.g. Anke Tresch and Manuel Fischer, 'In Search of Political Influence: Strategic Choices and Media Coverage of Political Parties, Interest Groups and Social Movements in Western European Countries,' International Political Science Review, 36(4), (2015):355-372; JeanFrederic Morin et al. The Politics of Transatlantic Trade Negotiations TTIP in a Globalized World. Farnham: Ashgate, 2015.

${ }^{10}$ Interview European Commission regular adviser, May 2016.

${ }^{11}$ On predictions see Leif Johan Eliasson, 'Problems, progress, and prognosis in trade and investment negotiations: the Transatlantic Free Trade and Investment Partnership' Journal of Transatlantic Relations, 14, no 2, (2014):119-139.

${ }^{12}$ Interview, Brussels, May 2016. Though the Commission's January 13, 2015 press release was strategically worded to balance recognition of opposition with a determination to find a compromise to ensure ISDS or ICS is included in a final agreement.

${ }^{13}$ Interview Brussels, May 2015. 
14 The focus in this paper is the effects of the campaign, not the accuracy and validity of opponents' arguments, which are separate issues addressed elsewhere, see Patrica Garcia-Duran and Leif Johan Eliasson, 'The Public Debate over TTIP and its Underlying Assumptions' Journal of World Trade 51, no. 1 (2017):23-42.

${ }^{15}$ Trade has traditionally, with few exceptions, been spared large-scale public mobilization and engagement, and instead been influenced mostly by insider lobbying from narrowly focused interests.

${ }^{16}$ cf. Matthias Bauer, 'Pferd(e) und Reiter in den Protest-Kampagnen um TTIP in Deutschland und Europa,' Policy Briefing Paper. European Centre for International Political Economy (2016) http://ecipe.org/app/uploads/2016/09/2016_09_01_Pferde-und-Reiter-in-den-ProtestKampagnen-um-TTIP-ECIPE-Policy-Brief_To_Go_rev-.pdf.

In addition to references provided, this section is based on several interviews with participants and observers in Brussels, May 2016, and Berlin (via telephone), June, 2016. The opposition to TTIP (and subsequently CETA) is strictly speaking a combination of individual (pan-European and national) organizations conducting activities to stop the agreement, but the StopTTIP umbrella alliance unifies hundreds of smaller groups. Many protests across Europe have been coordinated, and the resulting dominance of social media, resulting in (crucially) changing public opinion, provide the public and many policy makers with the impression of a coordinated opposition.

${ }^{17}$ Ferdi De Ville and Gabriel Siles-Brügges, TTIP: The Truth About the Transatlantic Trade and Investment Partnership London: Polity, 2015; Friends of the Earth Europe, 'Trading Away Our 
Future? A threat to Europe's democracy and environmental, health, and social safeguards' Position paper on TTIP, October 2013, https://www.foeeurope.org/sites/default/files/publications/foee_briefing_ttip_oct13.pd; Bauer, 2016, 'Pferde...'; 'Commentary by Thilo Bode: TTIP is not about blinkers' Foodwatch, November 11 (2014), https://www.foodwatch.org/en/what-we-do/news/commentary-by-thilobode-ttip-is-not-about-blinkers/?sword_list $\% 5 \mathrm{~B} 0 \% 5 \mathrm{D}=$ ttip; European Consumer Organization (BEUC), 'Consumers at the heart of the Transatlantic Trade and Investment Partnership.' Position Paper, May 21, (2014), http://www.beuc.eu/publications/beuc-x-2014031_mgo_ttip_updated.pdf.

${ }^{18}$ Andreas Dür, 'Interest Group Influence on Public Opinion: A Survey Experiment on the Transatlantic Trade and Investment Agreement.' Working Paper, April 25 (2015)

DOI: 10.13140/RG.2.1.3981.9683

${ }^{19}$ cf. Anne Binderkrantz, 'Different Groups, Different Strategies: How Interest Groups Pursue Their Political Ambitions,' Scandinavian Political Studies 31, no. 2, (2008):173200; Andreas Dür and Gemma Mateo, 'Public Opinion and Interest Group Influence: How Citizen Groups Derailed the Anti-Counterfeiting Trade Agreement,' Journal of European Public Policy 21, no. 8 (2014):1206.

${ }^{20}$ Eurobarometer 80 (2013) ; Special Eurobarometer 'Europeans 2014' (2014); Flash Eurobarometer 373 (2014), http://ec.europa.eu/COMMFrontOffice/publicopinion/index.cfm/General/index 
${ }^{21}$ Elizabeth Kensinger, 'What we remember (and forget) about positive and negative experiences,' Psychological Science Agenda, October 2011, http://www.apa.org/science/about/psa/2011/10/positive-negative.aspx

${ }^{22}$ Brian Möller-Jensen, Myter, Myte or Realitet, Herning: Systime (1988): 6-8; Cyrill Buffet and Beatrice Heuser, Haunted by History Myths in International Relations. Oxford, New York: Berghahn Books (1998); Leif Johan Eliasson, America's Perception of Europe, New York: Palgrave McMillan (2010)

${ }^{23}$ Raymond Nickerson, 'Confirmation Bias: A Ubiquitous Phenomenon in Many Guises,' Review of General Psychology. 2, no.2 (1998):175-220.

${ }^{24}$ cf. Buffet and Heuser, 1998; Heather Lamarre et al. (2009), 'The irony of satire: political ideology and the motivation to see what you want to see in The Colbert Report,' International Journal of Press/Politics, 14, no. 2 (2009): 212-231.

${ }^{25}$ cf. Jarrod Call and Brent Berry, 'The Dissemination of Knowledge and its Problems in American Democracy,' Public Knowledge Journal (e-version) 2, no.1.3 (2011);

Stephen Bennett, et al. 'Citizens' Knowledge of Foreign Affairs,' The Harvard International Journal of Press/Politics.1, no. 2 (1996):10-29; Buffet and Heuser, 1998; Möller-Jensen, 1998. ${ }^{26}$ Cf. Dür and Mateo 2014:1209. For more on salience, polarization (different beliefs and views), and actor expansion (different and greater number of groups involved) at different levels of engagement see e.g. Michael Zürn, 'Opening up Europe: next steps in politicization research,' West European Politics, 39, no.1, (2015):164-182, and the discussion in Niels Gheyle, 'Politisering van TTIP: een lont in het kruitvat' Internationale Spectator, 4 July, 2016. 
${ }^{27}$ Lucig Danielian and Benjamin Page, 'The heavenly chorus: interest group voices on TV news. American Journal of Political Science, 38 (1994):1072. For a discussion of the origin of mobilization, as the dependent variable, see Niels Gheyle, 'Adding fuel to the flames. How TTIP reinvigorated the politicization of trade,' Paper presented at Governance and Integration through Free Trade Agreements, Brussels, July 7-8, 2016.

${ }^{28}$ Cf. Bauer, 2016, 'Pferde...'; Matthias Bauer 'Manufacturing Discontent: The Rise to Power of Anti-TTIP Groups,' European Center for International Political Economy, Occasional Paper 02/2016 (2016); interview, Berlin, June 2016.

${ }^{29}$ Interview, Berlin, June, 2016.

${ }^{30}$ Cf. Bauer, 2016, 'Pferde...'; Bauer 'Manufacturing Discontent...' Excluding the 31 panEuropean organizations, the countries with the most vocal national groups are Germany (114), UK (25), and Austria and France (each 15). The most influential individuals on TTIP in Germany (where 2015-2016 saw an average of 1-2 TTIP related events per day across the country), are from the SDP and the Greens and Die Linke (Bauer, 2016, 'Pferde...':19-23), and left-leaning parties across the continent oppose TTIP, with many having well-anchored roots in the CSO community. For example, the German Left Party's spokesperson on TTIP Michael Efler is also CEO of More Democracy, an anti-trade group, and was co-founder of the 'Stop TTIP' initiative.

${ }^{31}$ Interview, CSO representative, Brussels, May 2016. As one representative noted, 'we exaggerate claims in order to generate publicity.' 
${ }^{32}$ Cf. BEUC, 2014. Sanitary and Phytosanitary (SPS) issues had previous public exposure dating back to the $1997 \mathrm{EU}$ ban on diluted chlorine washes for poultry and the 1998 World Trade Organization (WTO) row over the compatibility of EU SPS regulations with WTO rules, cf. Isis Sien, 'Beefing up the Hormones Dispute: Problems in Compliance and Viable Compromise Alternatives,' The Georgetown Law Review 95, no.2 (2007):566-590. The longstanding debate over Genetically Modified Organisms (GMOs) in Europe, where GMOs are widely opposed, and the 2016 EU Directive on GMOs (widely considered unworkable), have also helped keep food safety in the public realm.

${ }^{33}$ Marsha Echols, 'Food Safety Regulation in the European Union and the United States:

Different Cultures, Different Laws, Columbia Journal of European Law, 4, no. 2 (1998).

Eurobarometer 389, 2012

${ }^{34}$ Eurobarometer 354, 2010.

${ }^{35}$ BEUC, 2014:3-4.

${ }^{36}$ Eurobarometer 354, 2010.

${ }^{37}$ Eurobarometer 419, 2014.

38 'Evidence-based Union? A new alliance for science advice in Europe,' The Guardian June 23, 2013; 'Madness' of opposition to GM crops says Glover,' The Scotsman, October 20, 2013; 'Juncker Science The European Commission's chief scientific adviser falls afoul of the green lobby.' Wall Street Journal, December 1, 2014.

39 'Support in Principle for U.S.-EU Trade Pact, But Some Americans and Germans Wary of TTIP Details', Washington DC: Pew Research Center's Global Attitudes Project, 2014, 
http://www.pewglobal.org/2014/04/09/support-in-principle-for-u-s-eu-trade-pact/; Friends of the Earth Europe, 2013. These attacks include verbal accusations against American negotiators stakeholder meetings as witnessed by one of the authors in Brussels, February 4, 2015, where the US was accused by a prominent CSO of 'lacking any standards whatsoever.'

${ }^{40}$ Hans von der Burchard, 'The Man who Killed TTIP,' Politico, July 14, 2016, p. 10

${ }^{41}$ United Nations Conference on Trade and Development, 'Recent Developments in InvestorState Dispute Settlement,' New York and Geneva, 2014, http://unctad.org/en/PublicationsLibrary/webdiaepcb2014d3_en.pdf; cf. Susan Franck, 'Investor State Dispute Settlement: A Reality Check’ presentation at the Center for Strategic and International Studies, Washington, October 31, 2014; Susan Frank, 'Using Investor-State Mediation Rules to Promote Conflict Management: An Introductory Guide', Washington and Lee Public Legal Studies Research Paper Series 2014-13 (2014).

${ }^{42}$ Interview, union representative, Brussels, May 2016. Jan Kleinheisterkamp. Jan (2014), 'Is there a Need for Investor-State Arbitration in the Transatlantic Trade and Investment Partnership (TTIP)?' London: LSE Working Papers 10 (2014), http://dx.doi.org/10.2139/ssrn.2410188;

Marrti Koskenniemi, 'Investor Protection in TTIP: fading democracy or new generation?' presentation at the London School of Economics, February 18, 2014.

${ }^{43}$ Bauer in Flamant, 2015.

${ }^{44}$ Bauer in Flamant, 2015.

${ }^{45}$ E.g. BEUC, Corporate Observatory Europe.

${ }^{46}$ Bauer, 2016, 'Manufacturing...' 
${ }^{47}$ Cf. 'Reuters Institute Digital News Report 2015' Reuters Institute for the Study of Journalism, United Kingdom: Oxford (2015),

http://reutersinstitute.politics.ox.ac.uk/sites/default/files/Supplementary $\% 20$ Digital $\% 20 \mathrm{News} \% 2$ 0Report\%202015.pdf; 'Europeans Face the World Divided' Pew Global Attitudes Survey, June 13 (2016), http://www.pewglobal.org/2016/06/13/europeans-face-the-world-divided/

${ }^{48}$ European Commission, 'Issues paper Communicating on TTIP - Areas for cooperation between the Commission services and Member States'. Brussels: European Commission, November7 (2013), http://corporateeurope.org/trade/2013/11/leaked-european-commission-prstrategy-communicating-ttip

${ }^{49}$ See STOPTTIP!'s website listing, https://stop-ttip.org/supporting-organisations/

${ }^{50}$ E.g. Kleinheisterkamp, 2014.

${ }^{51}$ Public Citizen, TACD, Green MePs have frequently cited Vattenfall AB and others v. Federal Republic of Germany ICSID Case No. ARB/12/12 and Philip Morris Asia Limited v. The Commonwealth of Australia, UNCITRAL, PCA Case No. 2012-12, as examples, though the latter case was dismissed in December 2015. Investments, GMOs and chlorine chickens were three out the five issues most covered by the media in 201. Matthias Bauer, 'The Spiral of Silence - How Anti-TTIP Groups Dominate German Online Media and Set the Tone for TTIP Opinion,' European Center for International Political Economy, January 2015, http://ecipe.org/blog/anti-ttip-german-online-media/ 
${ }^{52}$ E.g. Corporate Observatory, 'ISDS: Spreading the disease instead of looking for a cure' May 6 (2015), http://corporateeurope.org/international-trade/2015/05/isds-spreading-disease-insteadlooking-cure.

${ }^{53}$ Natacha Cingotti, Pia Eberhardt, Nelly Grotefendt, Cecilia Olivet and Scott Sinclair, 'Investment Court System put to the test New EU proposal will perpetuate investors' attacks on health and environment', April (2016),

https://corporateeurope.org/sites/default/files/attachments/icstest_web.pdf

54 'EU Commission releases draft ISDS Proposal, Calling for Investment Court' and 'U.S.

Chamber, ISDS Critics Blast EU Investment Proposals; Parliament Praises' Inside US Trade, September 18, 2015.

${ }^{55}$ Bauer, 2016, 'Pferde...'

${ }^{56}$ Bauer, 2016, 'Pferde...'

${ }^{57}$ Matthias Bauer in Albane Flamant, 'TTIP: Lobby or not Lobby?’ April (2015), https://albaneflamant.atavist.com/ttiplobbying

${ }^{58}$ There were other observable developments resulting from interest group access. The erection of a TTIP advisory group in February 2014, the implementation of stakeholder presentations and debriefings during the week-long negotiation rounds beginning with the fourth round (held February 2014). While negotiators publicly state they learned much from these exercises, stakeholders were disappointed 'while a good idea and [we were] initially enthusiastic we realized little came from it', and business organizations largely ceased attending after six rounds, with one explaining 'we found it not useful after a few rounds.' Interviews, Brussels, May, 2016. 
${ }^{59}$ Graphs available online at EDITOR FILL IN DOI ADDRESS and from authors.

${ }^{60}$ While in general more searches tended to be conducted in Germany than in any other of the selected member states, the tendency in all six cases was toward an increase in searches during this period. Graphs available upon request, but they closely track Google searches.

${ }^{61}$ Author searches in October and November 2016.

${ }^{62}$ Graphs available online at EDITOR FILL IN DOI ADDRESS and from authors.

63 'Paris and Berlin call for review of E-Canada trade deal', Euractiv January 27, 2015, http://www.euractiv.com/section/trade-society/news/paris-and-berlin-call-for-review-of-eucanada-trade-deal/

${ }^{64}$ National parliaments, and six regional Belgian parliaments, had to approve CETA after the Commission decided for political reasons (CSO protests and growing public opposition) to propose ratification as a 'mixed agreement' (shared EU and national competencies).

${ }^{65}$ DeVille and Siles-Bürgge, 2015; Christian Oliver and Anca Gurzu, 'EU and Canada win a trade battle — but not the war,' Politico.eu, October 30, 2016, http://www.politico.eu/article/eu-and-canada-win-a-trade-battle-but-not-the-war.

${ }^{66}$ Eurobarometer 85 (2016).

${ }^{67}$ 'Open letter to the European Commission EU-US Trade negotiators,' Friends of the Earth Europe August 27, 2014, https://www.foeeurope.org/sites/default/files/27.08.2014_letter_to_cssr_de_gucht__safety_of_europe_food_is_under_threat.pdf 
${ }^{68}$ Anthony Faiola, 'Free trade with U.S.? Europe balks at chlorine chicken, hormone beef.'

Washington Post, December 4, 2014, https://www.washingtonpost.com/world/europe/free-tradewith-us-europe-balks-at-chlorine-chicken-hormone-beef/2014/12/04/e9aa131c-6c3f-11e4-bafd6598192a448d_story.html

cf. Friends of the Earth, 2014

${ }^{69}$ Pew, 2014.

${ }^{70}$ E.g. 'TTIP and the NHS: Don't be Fooled by New BBC Leak' War on Want, February 27

(2015), http://www.waronwant.org/media/ttip-and-nhs-dont-be-fooled-new-bbc-leak

${ }^{71}$ YouGov/38 Degrees, Survey, August 2014, https://d25d2506sfb94s.cloudfront.net/cumulus_uploads/document/umt71i8wcn/38degrees_resul ts_140826_TTIP_W(new\%20tabs).pdf

${ }^{72}$ YouGov, Survey, March, 2015, https://d25d2506sfb94s.cloudfront.net/cumulus_uploads/document/8h6hq2m8mr/March_Eurotra ck_Website.pdf

${ }^{73}$ Eurobarometer 82 (2014), 83 (2015); 83 (2016); cf. Bauer, 2015; Leif Johan Eliasson, 'The Transatlantic Trade and Investment Partnership: Interest Groups, Public Opinion, and Policy' in Patricia Garcia-Duran and Montserrat Millet, eds., Different Glances at EU Trade Policy, Barcelona: Barcelona Center for International Affairs, (2016):33-45.

74 The exchanges between MEPs in EPP, who approved of the resolution and were eager to vote, and the Socialist and Social Democratic group, were intense, even harsh, right up to the announcement of postponement, as observed by one of the authors. 
${ }^{75}$ Some research indicates that the receptivity to campaigns about how TTIP threatens food and public services (among other issues) is likely enhanced because of increased skepticism towards globalization and neoliberalism generally, as well as skepticism of America. One scholar found that especially people who reject the globalization process and oppose the EU also oppose TTIP. See Nils Steiner (2016) 'Public Support for TTIP in EU Countries: The Correlates of Trade Policy Preferences in a Salient Case' January 20, 2016, http://dx.doi.org/10.2139/ssrn.2718984 The problem with these findings is that support for the EU has remained steady as support for TTIP has fallen. Since support for trade generally has also remained high, Stein's study lends support for our research showing that framing by anti-TTIP campaigns is effective. 